\title{
Diallel analysis of pod yield and 100 seeds weight in peanut (Arachis hypogaea L.) using GRIFFING and HAYMAN methods.
}

Fidele Bawomon NEYA*a, SANON Elise ${ }^{a}$, Kadidia KOITA ${ }^{a}$, Bertin M'bi ZAGRE ${ }^{b}$, Philippe SANKARA ${ }^{a}$ aUniversité de Ouagadougou, (UFR/SVT), Département de Biologie Végétale et Physiologie Végétale, Laboratoire BIOSCIENCES, 03 BP 7021 Ouagadougou 03 Burkina Faso; bInstitut de l'Environnement et de Recherches Agricoles (INERA), Département Productions Végétales 04 BP 8645 Ouagadougou 04, Burkina Faso;

* E-mail: fidelebaw@yahoo.fr

Original submitted in on 20 June 2017. Published online at www.m.elewa.org on $4^{\text {th }}$ September 2017 http://dx.doi.org/10.4314/jab.v116i1.10

\section{ABSTRACT}

Objectives: The lack of information on yield and yield components are an obstacle in peanut (Arachis hypogaea L.) breeding for productivity improvement in BURKINA FASO. This work is to elucidate the mode of heritability of genes that govern 100 seed weight and pod yield, and identify the best parents for recommendation in hybridization programs.

Materials and methods: A 6 × 6 full diallel with breeding lines such as GM656, NAMA, PC79-79, AS, SH470P and CN94C; was conducted. Two models were used, one of GRIFFING (1956) and the second of HAYMAN (1954), to detect the general (GCA) and specific (SCA) combining ability. GCA/SCA < 1 for 100 seed weight and GCA / SCA > 1 for pod yield. D-H1 difference reveals existence of an over dominance for 100 seed weight and partial dominance for pods yield. Heritability in the narrow sense is $48.7 \%$ for the pod yield and $55.3 \%$ for the weight of 100 seeds.

Conclusion and Application of results: These results show that the pod yield is governed by genes with additive effects and non-additive effects with more additivity effects. However, the weight of 100 seed is essentially governed by genes with additive and non-additive effects with a preponderance of non-additive effects and dominance. HAYMAN graphical analysis indicates that CN94C, SH470P, AS have a lot more genes that control pods yield and 100 seed weight. These breeding lines may be recommended in hybridization for improvement of productivity. The importance of Reciprocal effects (RCE) shows that we must consider maternal effects in hybridization for breeding programs. In these programme

Keys word: Arachis hypogaea L. Yield; 100 seed weight, General Combining Ability; Specific Combining Ability.

\section{INTRODUCTION}

Peanut (Arachis hypogaea L.) genetic improvement consists of production of new varieties from existing varieties (cultivated or wild). The gene transfer is done from controlled crosses and selecting the best plants from these crosses (SANKARA, 1997).
CHAPMAN and NEAL in 1971 cited at least three reasons to estimate the importance of genetic variation in quantitative traits. It is to understand the fundamental genetic phenomena, know the gain in the selection of the heterozygous population and 
identify parents who can provide superior hybrids. Therefore, knowing the mode of inheritance of the most important characters for users is necessary for any work of improvement. Peanuts are one of the most important crops on which research on the genetics of quantitative traits is requested. The lack of information on yield and yield components are an obstacle in the selection for the improvement and productivity. Indeed, Sahara African countries, particularly Burkina Faso, still have not reached production levels sufficient to solve the problems of under nutrition or malnutrition. In addition, with the population growth in 2050 there will be more than nine billion people to feed (UN / World Population Prospects: The 2015 Revision; ANDRE G. 2015). Agricultural research therefore has work to increase yields to meet the food needs of people. Over the years, efforts have been made with the aim of improving the performance of the peanut, quality, disease resistance and other agronomic traits and resulting in improved features in peanut (Varshney et al., 2013). Improved varieties using conventional breeding through intraspecific hybridization and

\section{MATERIAL AND METHODS}

Experimental site: the experiment was conducted in the Institute of Rural Development (IDR) of Polytechnic University (Bobo-Dioulasso). The station is located in Gampela, $18 \mathrm{~km}$ in East from Ouagadougou. It is located in the central region. This is one of the regions with average rainfall in the country. The average precipitation is between $700 \mathrm{~mm}$ and $900 \mathrm{~mm}$. Rainfall is relatively short and lasts for about five months (June-October).

Vegetal material: Six varieties of Arachis hypogaea L., with different geographical origin and botanical types. AS interspecific, remains and plays an important role in increasing yields in peanut (Guo et al., 2012). Genetic improvement of yield in groundnut through hybridization and selection has more than doubled in the past; however, yield improvements have been slow in recent years (Hui W. et al., 2015). According Hui W. et al., 2015, one reason could be related to the limited genetic diversity of high efficiency parent used in hybridization programs. Parents with different origins have a higher probability to (Hui W. et al., 2015) produce superior progeny with those of similar ancestry, but it has become increasingly difficult to find high-yielding genotypes that do not have the common descent. In earlier research on heredity, according to Alam M. K. et al., 2013, all the additive effects (GCA) and non- additives (SCA) affects the control of most quantitative traits in peanut. The general objective of this work is to improve productivity in peanut breeding. In undertaking this study we (i) elucidate the mode of heritability of genes that govern 100 seed weight and pod yield; (ii) identify the best parents for recommendation in hybridization programs.

(Spanish) and NAMA (Virginia) are local lines. The GM656 is an introgression line of wild species. The crosses were made by Dr. Charles SIMPSON according to the following scheme: (FlorunnerTXAG x-6) BC3F3: 6 (C.E. SIMPSON, 1991; Simpson et al. 1993). PC79-79 (Virginia) is from ISRA-CNRA in Senegal CN94C (Spanish) type SH470P (Spanish) are INERA-Burkina. The characteristics of these lines are showed in the table 1.

Table 1: Some characteristics of parental lines

\begin{tabular}{l|l|l|l|l|l}
\hline Lines & Origin & Botanical type & Cycle (days) & seed & Leaf spot \\
\hline GM656 & USA (Lubbock) & Spanish & 110 & big & resistant \\
\hline NAMA & Burkina Faso & Virginia & 110 & small & resistant \\
\hline PC79-79 & ISRA/Sénégal & Virginia & 110 & big/average & resistant \\
\hline AS & Burkina Faso & Spanish & 90 & average & susceptible \\
\hline SH470P & Burkina Faso & Spanish & 90 & average & susceptible \\
\hline CN94C & Burkina Faso & Spanish & 90 & average & susceptible \\
\hline
\end{tabular}

Methods: two models were used, one of GRIFFING and the second of HAYMAN; that are complementary conventional methods that have been used to interpret the data from the diallel analysis for heritability. GRIFFING (1956) method detects the general combining ability (GCA) and specific combining ability (SCA). The 


\section{Neya et al., J. Appl. Biosci. 2017 Diallel analysis of pod yield and 100 seeds weight in peanut (Arachis hypogaea L.) using GRIFFING and HAYMAN methods.}

processing of data by this Combination (SCA) and giving information respectively on the additive effects and dominance; it is possible by the ratio of variance GCA / total variance, estimate the narrow heritability (RENE CHAUME et al. 1973). HAYMAN (1954) method, estimate different genetic components of nature and the various parameters namely additive, dominance, reciprocal effects, heterosis and heritability.

Data analysis: The data collected in the performance study (100 seed weight and pods yield) were analyzed

\section{RESULTS}

Analysis by GRIFFING method: Analysis of variance performed on 100 seed weight of 36 entries indicates the existence of a very highly significant difference between these. The results are reported in Table 2. An average of with the DIAL software 98. This software has allowed us to estimate genetic parameters of each component, and to appreciate the General and Specific combining ability. The results of analysis of our data, provided by this program have been interpreted through GRIFFING and HAYMAN models. Analysis of variance was done with the software Version 8.1- Statistix 2005. Results were expressed mainly in the form of tables and figures.

$25.5 \mathrm{~g}$ is noted for 100 seed weight and $0.86 \mathrm{t} /$ ha yields. This analysis allows checking the variability within F1. Coefficients of variation were 7.47 respectively for the 100 seeds weight of and 30.25 for pods yield.

Table 2: ANOVA of 36 entries for yield 100 seeds weight.

\begin{tabular}{|c|c|c|c|c|c|c|c|c|c|}
\hline \multirow[t]{2}{*}{ Source } & \multirow[t]{2}{*}{ ddl } & \multicolumn{2}{|c|}{ (SS) } & \multicolumn{2}{|c|}{ (MS) } & \multicolumn{2}{|c|}{$F$} & \multicolumn{2}{|c|}{ Probability } \\
\hline & & $\begin{array}{l}\text { weight } \\
\text { 100seed }\end{array}$ & yield & $\begin{array}{c}\text { weight } \\
\text { 100seed }\end{array}$ & yield & $\begin{array}{c}\text { weight } \\
\text { 100seed }\end{array}$ & yield & $\begin{array}{l}\text { weight } \\
100 \text { seed }\end{array}$ & yield \\
\hline Repetition & 02 & 66.24 & 1.51 & 33.12 & 0.75 & & & & \\
\hline Entries & 35 & 955.52 & 9.95 & 27.30 & 0.28 & 7.69 & 4.14 & $0.0001^{* \star \star}$ & $0.0001^{\star \star \star}$ \\
\hline Error & 70 & 248.36 & 4.81 & 3.54 & 0.06 & & & & \\
\hline C.V & & 7.47 & 30.25 & & & & & & \\
\hline Mean & & & & & 21 & 0.86 & & & \\
\hline
\end{tabular}

Analysis of variance results of effects associated with the general combining ability (GCA), specific combining ability (SCA) and reciprocal effects RCE are reported in Table 3. The results indicated for 100 seed weight a nonsignificant GCA, however for pod yield is significant. The results of the SCA indicate that it is highly significant for 100 seed weight and significant for pods yield. The reciprocal effects reported in Table show that they are highly significant for 100 seed weight and significant for pods yield. The ratio Var GCA/Var SCA is less than 1 for 100 seed weight $(0.60)$, and greater than 1 for pods yield (1.20). The table 3 shows the average of thirty-six (36) entries with six parents and 30 crosses. The SH47OP and GM656 have the higher 100 seeds weight. The CN94C, AS and GM656 and SH70P have the highest yields. Several crosses involving these lines have a weight of 100 seeds, and yield above the average.
Analysis by HAYMAN method: The estimation results of the genetic components of the 100 seed weight and pods yield characteristics are shown in Table 5. Analysis indicates a negative difference between the additive variance $\mathrm{D}$ (lower) and $\mathrm{H} 1$ dominance genetic variance (upper) for weight of 100 seed. For the pods yield there is a positive difference with the additive variance $D$ greater than the $\mathrm{H} 1$ dominance genetic variance (less). The estimated heritability in the broad sense and in the narrow sense indicated for 100 seed weight respectively $81.7 \%$ and $48.7 \%$. For the pod yield, heritability is $71.2 \%$ and $55.3 \%$ respectively in the broad sense and narrow sense. It is noted for parents and F1 a slight difference in pods yield and of 100 seed weight average, with an increase in F1. 
Neya et al., J. Appl. Biosci. 2017 Diallel analysis of pod yield and 100 seeds weight in peanut (Arachis hypogaea L.) using GRIFFING and HAYMAN methods.

Table3: Means of 100 seed and pod yield of F1 population

\begin{tabular}{|c|c|c|c|c|}
\hline \multicolumn{5}{|c|}{ Means of 100 seed of F1 population } \\
\hline \multicolumn{3}{|c|}{ Groups crosse 100 seeds weight } & \multicolumn{2}{|c|}{ Groups crosse 100 seeds weight } \\
\hline$a$ & ASxGM656 & 30 & abcdefg CN94C & 25.77 \\
\hline$a b$ & GM656XSH470P & 29.2 & abcdefg NAMAxSH470P & 25.43 \\
\hline$a b$ & PC79-79xCN94C & 28.63 & abcdefg NAMAxAs & 25.27 \\
\hline$a b$ & ASxSH470P & 28.27 & abcdefg SH470PxGM656 & 625.27 \\
\hline$a b c$ & SH470PxNAMA & 28.13 & abcdefgh CN94CXAs & 24.77 \\
\hline$a b c$ & GM656xAS & 28.03 & abcdefgh PC79-79xGM6 & 5624.67 \\
\hline$a b c$ & SH470PxPC79-79 & 28.03 & abcdefgh AS & 24.1 \\
\hline$a b c$ & GM656xCN94C & 27.93 & abcdefgh CN94CXPC79- & 7923.9 \\
\hline$a b c$ & PC79-79xAS & 27.87 & bcdefgh ASxNAMA & 23.77 \\
\hline$a b c$ & PC7979xSH470P & 27.87 & bcdefgh NAMAxPC79-7 & 7923.6 \\
\hline abcd & SH470PxAS & 27.3 & bcdefgh GM656XPC79- & 7923.53 \\
\hline abcd & NAMAXCN94C & 27.27 & cdefgh $\quad$ ASxPC79-79 & 22 \\
\hline abcd & SH470P & 26.73 & defgh PC79-79xNAMA & 21.57 \\
\hline abcde & e ASxCN94C & 26.47 & efgh $\quad$ PC79-79 & 20.5 \\
\hline$a b c d e$ & e GM656 & 26.4 & NAMA & 20.2 \\
\hline$a b c d e$ & le SH470PxCN94C & 26.37 & CN94CxNAMA & 19.63 \\
\hline$a b c d e$ & lef CN94CxGM656 & 26 & GM656xNAMA & 18.83 \\
\hline$a b c d e$ & lef CN94CxSH470P & 25.83 & NAMAxGM656 & 18.7 \\
\hline F Tes & & & 7.69 & \\
\hline CV & & & 7.47 & \\
\hline Pro. & & & & $3.2 \mathrm{e} 13^{\star * \star}$ \\
\hline Mean & & & 25.20 & \\
\hline
\end{tabular}

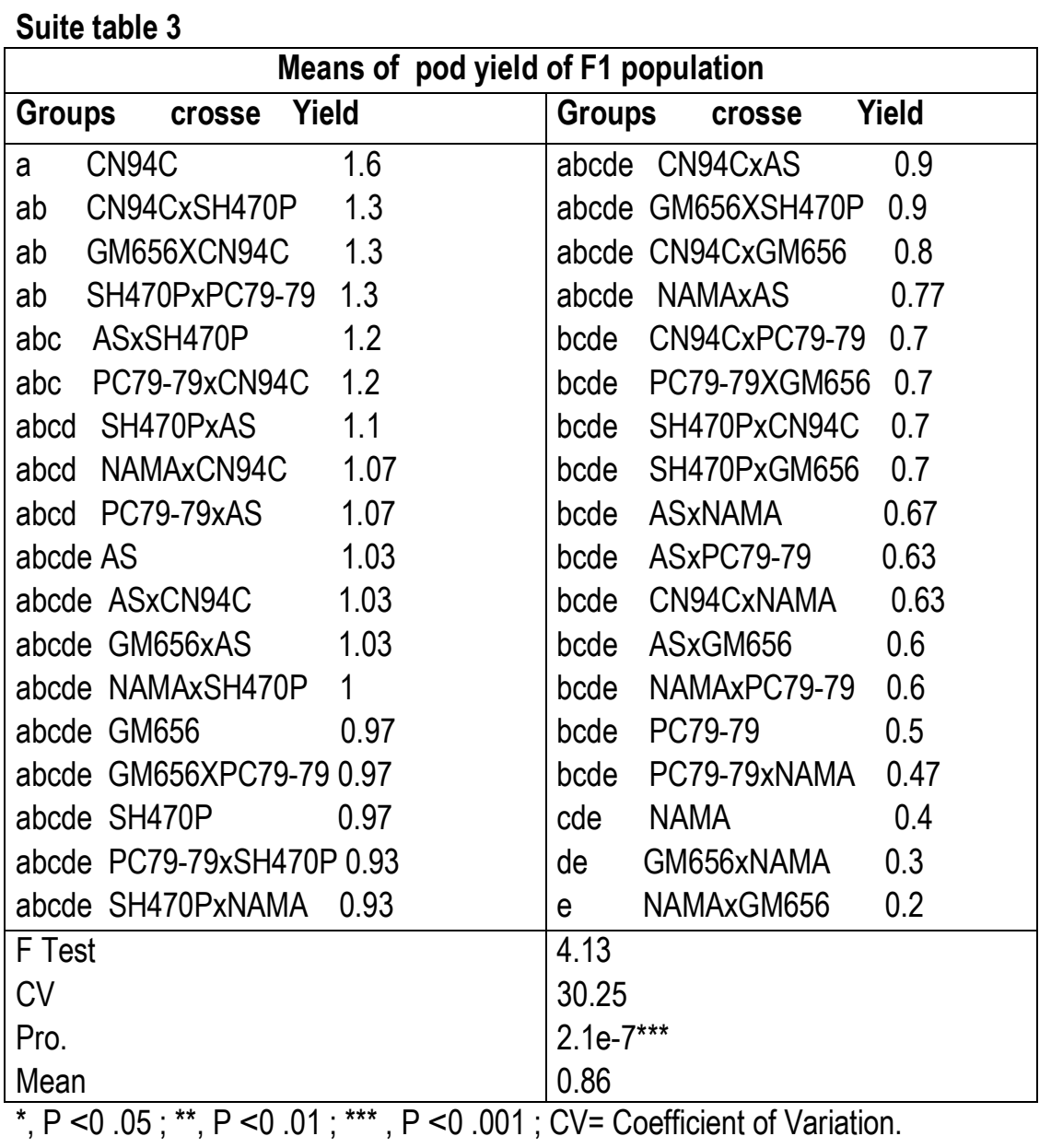

Prob.= Probability 
Neya et al., J. Appl. Biosci. 2017 Diallel analysis of pod yield and 100 seeds weight in peanut (Arachis hypogaea L.) using GRIFFING and HAYMAN methods.

Table 4: Means of 100 seed and pod yield of $F 1$ population

\begin{tabular}{|c|c|c|c|}
\hline $\begin{array}{l}\text { Groups crosses } \\
100 \text { seeds weight }\end{array}$ & $\begin{array}{l}\text { Groups crosses } \\
100 \text { seeds weight }\end{array}$ & $\begin{array}{c}\text { Groups crosses } \\
\text { Yield }\end{array}$ & $\begin{array}{c}\text { Groups crosses } \\
\text { Yield }\end{array}$ \\
\hline ASxGM656 30 & $\begin{array}{ll}\text { abcdefgCN94C } \quad 25.77 \\
\end{array}$ & aCN94C & abcde CN94CxAS 0.9 \\
\hline GM656XSH470P 29.2 & abcdefg NAMAxSH470P 25.43 & ab $\quad$ CN94CxSH470P 1.3 & abcde GM656XSH470P \\
\hline PC79-79xCN94C 28.63 & abcdefgNAMAxAs25.27 & ab GM656XCN94C 1.3 & abcde CN94CxGM656 \\
\hline ASxSH470P 28.27 & abcdefg SH470PxGM656 25.27 & ab $\quad$ SH470PxPC79-79 1.3 & $\begin{array}{ll}\text { abcdeNAMAxAS } & 0.77 \\
\end{array}$ \\
\hline abc $\quad$ SH470PxNAMA 28.13 & abcdefgh CN94CxAs 24.77 & $\begin{array}{lll}\text { abc } & \text { ASxSH470P } & 1.2 \\
\end{array}$ & bcde $\quad$ CN94CxPC79-79 0.7 \\
\hline abc $\quad$ GM656xAS 28.03 & abcdefgh PC79-79xGM656 24.67 & abc PC79-79xCN94C 1.2 & PC79-79XGM656 \\
\hline abc $\quad$ SH470PxPC79-79 28.03 & $\begin{array}{ll}\text { abcdefghAS } & 24.1 \\
\end{array}$ & abcd SH470PxAS 1.1 & SH470PxCN94C \\
\hline abc $\quad$ GM656xCN94C 27.93 & abcdefgh CN94CxPC79-79 23.9 & abcd NAMAxCN94C 1.07 & $\begin{array}{lll}\text { bcde } & \text { SH470PxGM656 } & 0.7 \\
\end{array}$ \\
\hline $\begin{array}{lll}a b c & \text { PC79-79xAS } 27.87 \\
\end{array}$ & $\begin{array}{ll}\text { Bcdefgh ASxNAMA } & 23.77 \\
\end{array}$ & $\begin{array}{lll}\text { abcd } & \text { PC79-79xAS } & 1.07 \\
\end{array}$ & $\begin{array}{ll}\text { bcdeASxNAMA } & 0.67 \\
\end{array}$ \\
\hline $\begin{array}{ll}\text { abc } & \text { PC7979xSH470P } 27.87 \\
\end{array}$ & bcdefgh NAMAxPC79-79 23.6 & $\begin{array}{ll}\text { abcdeAS } & 1.03 \\
\end{array}$ & bcde ASxPC79-79 \\
\hline $\begin{array}{lll}\text { abcd } & \text { SH470PxAS } 27.3\end{array}$ & bcdefgh GM656XPC79-79 23.53 & $\begin{array}{ll}\text { abcde ASxCN94C } \quad 1.03 \\
\end{array}$ & CN94CXNAMA \\
\hline abcd NAMAxCN94C 27.27 & cdefgh ASxPC79-79 22 & abcde GM656xAS 1.03 & bcde $\quad$ ASxGM656 $\quad 0.6$ \\
\hline $\begin{array}{lll}\text { abcd } & \text { SH470P } & 26.73 \\
\end{array}$ & defgh PC79-79xNAMA 21.57 & abcde NAMAxSH470P 1 & bcde $\quad$ NAMAxPC79-79 0.6 \\
\hline abcde ASxCN94C 26.47 & efghPC79-79 20.5 & $\begin{array}{ll}\text { abcdeGM656 } & 0.97 \\
\end{array}$ & $\begin{array}{ll}\text { bcdePC79-79 } & 0.5 \\
\end{array}$ \\
\hline $\begin{array}{lll}\text { abcde } & \text { GM656 } & 26.4 \\
\end{array}$ & $\begin{array}{ll}\text { fghNAMA } & 20.2 \\
\end{array}$ & abcde GM656XPC79-79 0.97 & bcde $\quad$ PC79-79xNAMA 0.47 \\
\hline abcde SH470PxCN94C 26.37 & gh $\quad$ CN94CxNAMA 19.63 & $\begin{array}{ll}\text { abcdeSH470P } & 0.97\end{array}$ & $\begin{array}{lll}\text { cde } & \text { NAMA } & 0.4 \\
\end{array}$ \\
\hline abcdef CN94CxGM656 26 & GM656xNAMA 18.83 & abcde PC79-79xSH470P 0.93 & GM656xNAMA 0.3 \\
\hline abcdef CN94CxSH470P 25.83 & NAMAxGM656 18.7 & abcde SH470PxNAMA 0.93 & e $\quad$ NAMAxGM656 \\
\hline F Test & 7.69 & & 4.13 \\
\hline CV & 7.47 & & 30.25 \\
\hline Pro. & $3.2 e-13^{* * *}$ & & $2.1 e-7^{* * *}$ \\
\hline Mean & 25.2 & & 0.86 \\
\hline
\end{tabular}

${ }^{*}, \mathrm{P}<0.05 ;{ }^{* *}, \mathrm{P}<0.01 ;{ }^{* * *}, \mathrm{P}<0.001 ; \mathrm{CV}=$ Coefficient of Variation. Prob. = Probability 


\section{Neya et al., J. Appl. Biosci. 2017 Diallel analysis of pod yield and 100 seeds weight in peanut (Arachis}

hypogaea L.) using GRIFFING and HAYMAN methods.

Table 5: Estimation of genetic parameters of the weight of 100 seeds and pods yield according to HAYMAN

\begin{tabular}{l|l|l|l|l}
\hline \multirow{2}{*}{ Genetic parameters } & \multicolumn{2}{|c|}{ Weight of $\mathbf{1 0 0}$ seeds } & \multicolumn{2}{c}{ Pods Yield } \\
\cline { 2 - 5 } & Value & Deviation & Value & Deviation \\
\hline $\mathrm{E}:$ environnemental Variance & 1.37 & 0.22 & 0.02 & 0.003 \\
\hline $\mathbf{D}:$ additive variance & 6.72 & 3.04 & 0.09 & 0.04 \\
\hline $\mathrm{H}_{1}:$ non additive variance 1 & 10.47 & 3.86 & 0.06 & 0.05 \\
\hline $\mathrm{H}_{2}:$ non additive variance 2 & 9.92 & 3.23 & 0.04 & 0.03 \\
\hline $\mathrm{F}:$ Product of add. By dom. effects & -0.007 & 3.18 & 0.02 & 0.05 \\
\hline Mp:Mean of parents & 23.85 & 0.48 & 0.85 & 0.06 \\
\hline $\mathbf{M F}:$ Mean of F1 & 25.63 & 0.22 & 0.86 & 0.02 \\
\hline $\mathrm{H}^{2} \mathbf{b}:$ Heritability in a broad sense (\%) & $\mathbf{8 1 . 7}$ & 3.6 & $\mathbf{7 1 . 2}$ & 0.58 \\
\hline $\mathbf{h}^{2} \mathbf{n}:$ Heritability in a narrow sense (\%) & $\mathbf{4 8 . 6}$ & 7.1 & $\mathbf{5 5 . 3}$ & 0.87 \\
\hline Sqr(H1/D) Average degree of dominance & $\mathbf{1 . 2 4}$ & 0.35 & $\mathbf{0 . 8 6 5}$ & 0.326 \\
\hline $\mathbf{D}-\mathrm{H}_{1}:$ (type of dominance) & $-\mathbf{3 . 7 5}$ Over dominance & $\mathbf{0 . 0 3}$ Partial Dominance \\
\hline
\end{tabular}

Diallel table analysis: Analysis of variance results of 100 seed weight and pods yield are shown in Table 6 . The results for 100 seeds weight are some differences similar to them showing by GRIFFING analysis. Indeed, the additive "a" corresponding to the GCA in HAYMAN is highly significant, that is not the case with GRIFFING. Dominance "b" corresponding to the SCA is highly significant as showing in GRIFFING analysis. The means and reciprocal maternal effects, respectively marked "c" and "d" representing ERC (reciprocal effect in the model of GRIFING) are significant. The sense of dominance "b1" is highly significant, for against the direction of the distribution of genes "b2" is not significant. The term "b3" representing the SCA itself is highly significant. The results for pods yield are similar to those of analysis of GRIFFING. Additivity "a" is highly significant and dominance "b" significant. They correspond to the GCA and SCA. The sense of dominance "b1" is not significant. The sense of the distribution of genes "b2" as SCA itself "b3" are significant. The means and reciprocal maternal effects are also significant.

Table 6: Variance analysis of the terms of HAYMAN 1954a

\begin{tabular}{|c|c|c|c|c|c|c|c|}
\hline \multirow[t]{2}{*}{ Source } & \multirow[t]{2}{*}{ Meaning } & \multicolumn{2}{|c|}{ Mean Square } & \multicolumn{2}{|c|}{ F. probability } & \multicolumn{2}{|c|}{ significance } \\
\hline & & $\begin{array}{l}\text { 100seeds } \\
\text { weight }\end{array}$ & yield & $\begin{array}{l}\text { 100seeds } \\
\text { weight }\end{array}$ & yield & $\begin{array}{l}\text { 100seeds } \\
\text { weight }\end{array}$ & yield \\
\hline a & additivity & 63.32 & 0.83 & 17.05 & 12.68 & $* *$ & ** \\
\hline b & dominance & 19.75 & 0.14 & 4.58 & 2.07 & ** & * \\
\hline b1 & Dominance direction & 56.20 & - & 11.50 & - & ** & ns \\
\hline b2 & Genes distribution & 8.94 & 0.16 & 1.68 & 2.43 & ns & * \\
\hline b3 & ASC & 21.70 & 0.14 & 5.42 & 2.10 & ** & * \\
\hline c & Maternal effect & 5.14 & 0.21 & 3.85 & 3.24 & * & * \\
\hline $\mathrm{d}$ & Reciprocal & 4.10 & 0.14 & 2.58 & 2.19 & * & * \\
\hline
\end{tabular}

${ }^{*}, \mathrm{P}<0.05 ;{ }^{* *}, \mathrm{P}<0.01 ;{ }^{* * *}, \mathrm{P}<0.001 ; \mathrm{ns}, \mathrm{P}>0.05$

Graphical analysis by HAYMAN Method for 100 seed weight: This is the graphic representation of $\mathrm{Wr}(r$ covariance between a parent and its descendants) according to $\mathrm{Vr}$ ( $r$ Variance of a parent and its descendants). Figure 1 is the graph for 100 seed weight. It is noted in the figure, the presence of three curves: Regression line $(\mathrm{Wr}=\mathrm{y}=0.66 \mathrm{Vr}+0.34)$, the tangent to the parabola $\left(\mathrm{Wr} 1=\mathrm{y}_{1}=1.0 \mathrm{Vr}+2.37\right)$ and finally, the parable $\mathrm{W}^{\wedge} \mathrm{r} 2=\mathrm{y}^{2}=9.49 \mathrm{Vr}$. Two extremes are to be considered are the points $M$ and $M$ 'corresponding to the intersections between the regression line and parabola. We note in the figure that $\mathrm{CN} 94 \mathrm{C}, \mathrm{SH} 470 \mathrm{P}$ and AS are close to the origin of the intersection, NAMA, PC7979, GM656 occupy a middle position. 


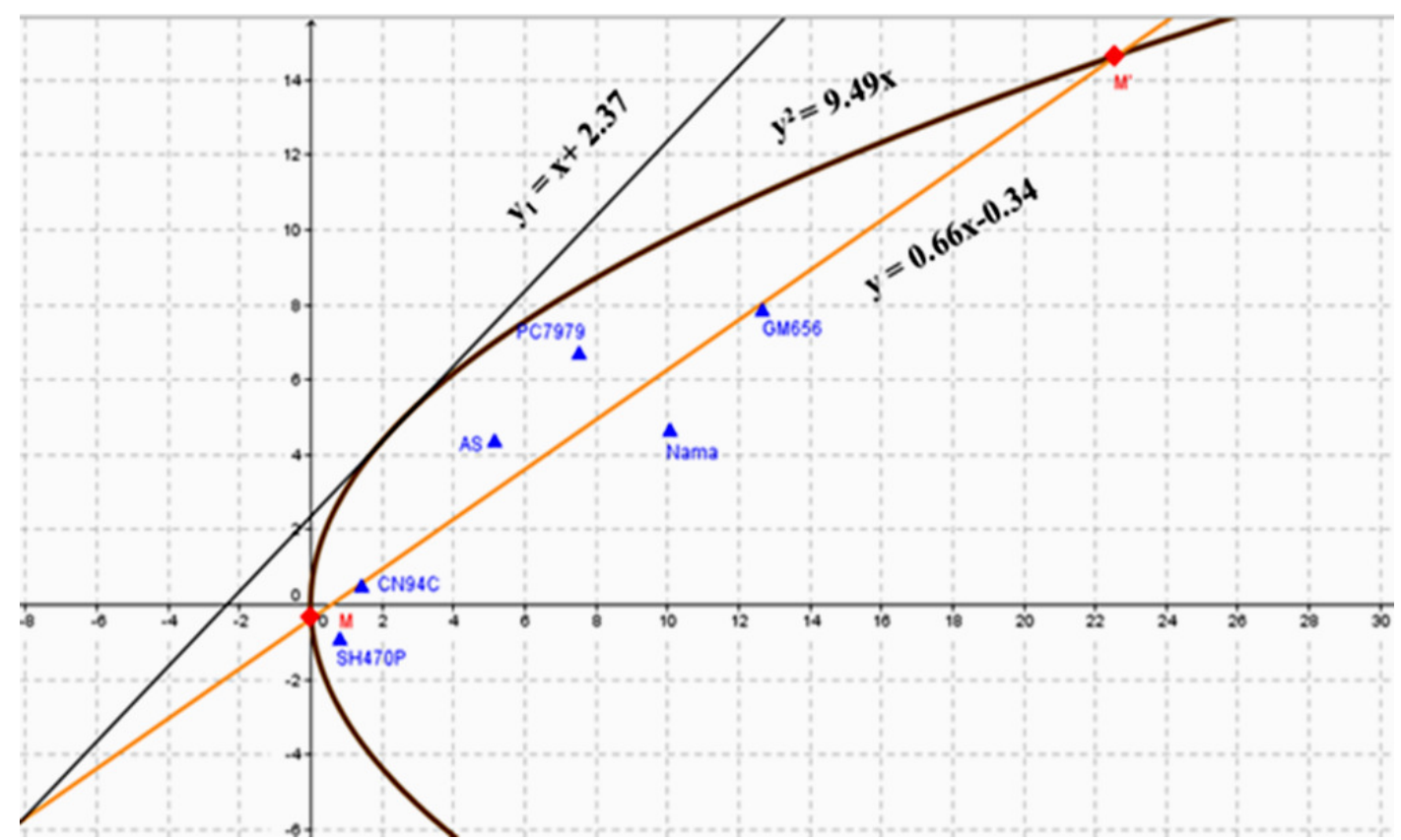

Figure 1: Graphical representation according to the HAYMAN model of the covariance Wr as a function of the variance $\operatorname{Vr}$ for the weight of 100 seeds.

Graphical analysis by HAYMAN method for pod yield

Figure 2 is a graphical representation of $\mathrm{Wr}$ ( $\mathrm{r}$ covariance between a parent and its descendants) according to $\operatorname{Vr}(\mathrm{r}$ variance of a parent and its descendants) for pods yield. Here, the regression line $\mathrm{Wr}=\mathrm{y}=0.52+0.008 \mathrm{Vr}$. The graph analysis indicates that AS, CN94C and SH470P are close to the origin of the intersection of the regression line with the parabola. The lines PC79-79, GM656 and NAMA are also close to $M$.

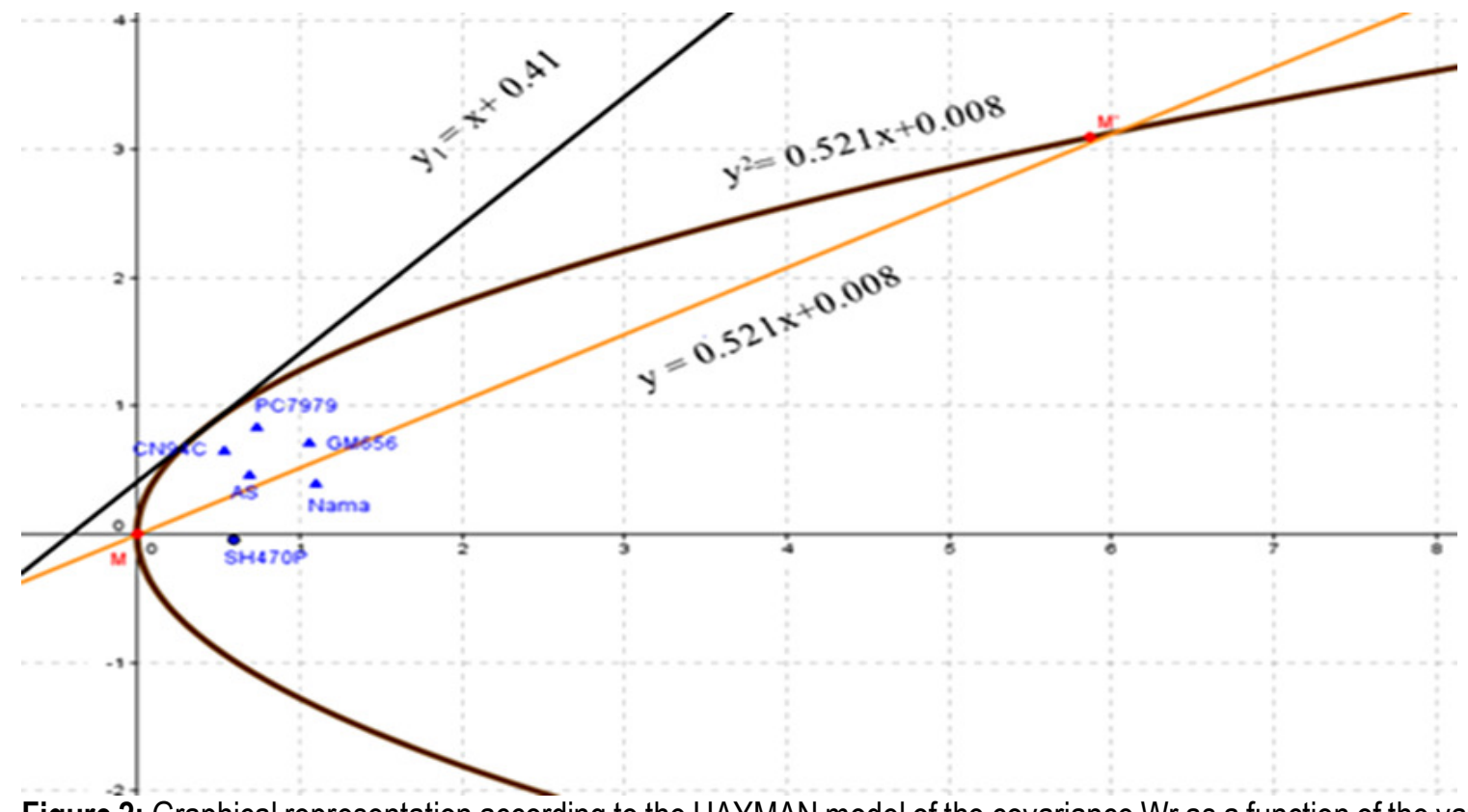

Figure 2: Graphical representation according to the HAYMAN model of the covariance Wr as a function of the variance $\mathrm{V} r$ for the pod yield. 


\section{Neya et al., J. Appl. Biosci. 2017 Diallel analysis of pod yield and 100 seeds weight in peanut (Arachis hypogaea L.) using GRIFFING and HAYMAN methods.}

\section{DISCUSSION}

The results of the analysis in relation to pods yield and 100 seed weight show that GCA, SCA and the ERC are significant to varying degrees as well as the model of GRIFFING than HAYMAN. These abilities and reciprocal effects were significant for pods yield and highly significant for 100 seed weight. This indicates their involvement in the expression of productivity in these breeding lines. HAYMAN analysis showed highly significant additive and non-additive effects for 100 seed weight and significant effects for pods yield. ZAGRE (2004) showed that there are significant additive effects on pod yield and number of pods per plant. In this study analysis on breeding lines using GRIFFING method reveals a significant difference in the GCA (additive) and SCA (not additive) for pod yield; however, for 100 seed weight, AGC is not significant and the SCA is very significant. GCA / SCA ratio indicates preponderance of SCA for 100 seed weight where the ratio is less than 1 and the GCA preponderance for pod yield, where ratio is greater than 1 . These results thus show that the pod yield is governed by genes with additive effects and not additive effects with mainly additivity effects and dominance. However, genes with no additive and additive effects essentially govern 100 seed weight with a preponderance of non-additive and dominance. Unlike this study results, Jagannadha REDDY and RAJA, REDDY (1987) found that the additive effects were predominant in controlling heredity weight of 100 seeds. UPADHAYAYA et al (1992) in their analysis of combining ability in groundnut had found the existence of effects not additives seed weight per plant. ALAM M. K. et al., 2013 who worked on the analysis of combining ability of yield and some associated character traits, indicates the preponderance of the additive in the inheritance of these traits; but for 100 seed weight, it is not additive effects, which would control the character. However, they worked on a half diallel. The significance of SCA demonstrates that for an advantageous hybridization program on peanut, for improved performance, a choice of individuals responding to the expectations of production is necessary. The ERC highly significant effects, depending on GRIFFING method, for 100 seed weight and for pod yield are confirmed by HAYMAN model, for both characters. This shows existence of maternal effects and effects of reciprocity. Therefore, in the selection for improved performance, the direction in breeding programs is to be considered. This would optimize the desired performance improvement with timesavings. The non-significance of the term "b1" from Hayman analysis shows that there is therefore a bi-directional dominance of genes. This would mean that dominant genes for positive and negative effects coexist in the genotypes of the parents. The term "b2" is significant this indicates an asymmetric distribution with some parents focusing more genes than others in the pod yield. For 100 seed weight, dominance is unidirectional. AHMED N. 1995 reported the importance of effects not additives in heredity and performance of these components. PARMAR et al 2000 showed that the GCA and SCA were significant for pod yield; the ginning percentage and 100 seed weight. JIVANI et al., 2009 also reported that the abilities (GCA) general and specific (SCA) to the combination were significant. HARIPRASANNA et al. 2008 had already indicated it but insisting that the SCA played an equal role in weight control seeds. The results of the heritability in a broad sense and in the narrow sense are $81.7 \%$ and $48.7 \%$ respectively for 100 seed weight, and those for the pod yield of $71.2 \%$ and $55.3 \%$ respectively. MARTIN (1967) who worked on heredity performance, rich in oil and weight of 100 seeds, had described these characters very heritable with respectively $70 \%$ for the first two characters and $66 \%$ to $76 \%$ in 100 seed weight. ALAM M. K. et al., 2013 found in their study in the strict sense heritability of $35 \%$ for weight and 100 pods for pod yield per plot in the strict sense heritability of $41 \%$. According to NTARE (2013), selection for low heritable agronomic traits such as pod yield is difficult in the genealogical tree nurseries, because of the significant effect of environmental heterogeneity on these characters. It is important to note that the large variation in the level of heritability of the characters would be mainly related to the environment. Although phenotypic selection undergoes the interactions of the environment that affect heritability and ignorance of genes involved, it is nevertheless the basis of substantial progress for yield (ANDRE G., 2015).The values of heritability and the value of environmental change given by the results of the estimated genetic parameters (Table 4) indicate that the environmental effects are not zero on the control of characters. The D-H1 differences indicate that there is an over-dominance in the genetic control of 100 seed weight because the value of the difference is -3.75 (negative) and partial dominance in the genetic control of pod yield with a value of 0.03 (positive value). ALAM M. K. et al., 2013 who worked on several characters whose 100 seed weight and pod yield had found the existence of overdominance for these traits. This result is a similar proportion to what we got for 100 seed weight but contrary to pod, yield or we found a partial dominance. 


\section{Neya et al., J. Appl. Biosci. 2017 Diallel analysis of pod yield and 100 seeds weight in peanut (Arachis hypogaea L.) using GRIFFING and HAYMAN methods.}

The results of the graphical analysis are a few differences like the two characters pod yield and 100 seed weight. The GM656, NAMA, PC79-79 are more medially on weight of 100 seed graphical than graphical dedicated to the pod yield, but it is clear from these different positions that these parental lines concentrated in them in almost the same proportions and recessive genes dominant

\section{ACKNOWLEDGEMENTS}

L'Université Ouaga I Joseph KI-ZERBO; le Fond National pour l'Education et la Recherché; le Laboratoire BIOSCIENCES de I'Université Ouaga I Joseph KI-

\section{CONCLUSION}

The study of these quantitative traits was based on statistical analysis of performance of breeding lines involved in the study. It is the same for the selection methods in the different domestic species, plant or animal. Following this study, it appears the existence of additive effects and non-additive effects in controlling 100 seed weight and pod yield. However, the pods yield is much under the control of additive effects, while the weight of 100 seed is under the control of non-additive effects. Heritabilities in the broad sense of these

\section{REFERENCES}

Andre G. 2015 Comprendre l'amélioration des plantes Enjeux, méthodes, objectifs, et critères de sélection Editions Quae Collections Synthèses 240p. ISBN 978-2-7592-2346-6 Réf. 02487

B R Ntare, 2013. Groundnut breeding training modules. International Crops Research Institute for the Semi-Arid-Tropic viii + 91pp.

Griffing B. 1956.Concept of general and specific combining ability in relation to diallel crossing system. Austr J. Biol. Sci. 9: 463-93.

Guo BZ, Chen CY, Chu Y, Holbrook CC, Ozias-Akins P, Stalker HT (2012) Advances in genetics and genomics for sustainable peanut production. In: Benkeblia N, ed. Sustainable Agriculture and New Biotechnologies. CRC Press, Boca Raton, FL. pp. 341-367.

Hariprasanna K, ChuniLal, Radhakrishnan T, Gor H K and Chikani B M (2008) Analysis of diallel cross for some physical-quality traits in peanut (Arachis hypogaea L.). Euphytica160: 49-57

Hayman B. 1994 The theory and analysis of diallel crosses. Genetics; 39: 789-809.

Hui Wang; PawanKhera; Bingyan Huang; Mei Yuan; Ramesh Katam; WeijianZhuang; Karen HarrisShultz; Kim M. Moore; Albert K. Culbreath; genes for expression efficiency. AS, SH470P and CN94C lying much closer to the origin of the point $\mathrm{M}$, they focus on dominant genes for yield. This indicates that the performance would be under the control of dominant genes to the extent that these lines called sensitive lines recorded the largest production.

ZERBO. L'Institut du Développement Rural (IDR) de I'Université polytechnique de Bobo-Dioulasso.

characters were respectively 81.7 and 71.2 for 100 seed weight and pods yield. In the narrow sense, heritabilities were 48.7 for the 100 seed weight and for pods yield 55.3 Access to the genome of organisms would probably a better understanding of the inheritance of quantitative traits and could help improve the effectiveness of selection programs through timesavings and efficiency results. An agro-morphological and molecular characterization of these parental lines would be very necessary.

Xinyou Zhang; Rajeev K. Varshney; LianhuiXie; And BaozhuGuo 2015 Analysis of genetic diversity and population structure of peanut cultivars and breeding lines from China, India and the US using simple sequence repeat markers. In: Journal of Integrative Plant Biology May 2016, Volume 58, Issue 5; pp. 452-465

Jagannadha Reddy B and Raja Reddy C (1987) Estimation of heterosis in intra - sub - specific crosses of groundnut. J. Oilseeds Rese., 4: 249-251.

Jivani L L, Khanpara M D, Kachhadia V H and Vacchani $\mathrm{JH}$ (2009) Combining ability for pod yield and its components in groundnut (ArachishypogaeaL) International J. Agric. Sci., 5: 248-250.

L. S. Kumar, 1999 "DNA markers in plant improvement: an overview," Biotechnology Advances, vol. 17, no. 2-3, pp. 143-182.

M. K. Alam, U. K. Nath, M. A. K. Azad, M. A. Alam and A. A. Khan 2013. Combining ability analysis for yield and yield contributing traits of groundnut. Journal of Science and Technology 11(2013): 106-111

M.K. Alam, U.K. Nath, M.A.K. Azad, M.A. Alam and A.A. Khan , 2013 Genetic analysis of some 

hypogaea L.) using GRIFFING and HAYMAN methods.

agronomic traits in groundnut (Arachis hypogaeaL.) Int. J. Agril. Res. Innov. \& Tech. 3 (2): 31-35 ISSN: 2224-0616

Martin J.P. 1967 Contribution à l'étude de certains caractères d'importance agronomique chez l'arachide. Etude de l'hérédité de la richesse en huile du rendement au décorticage et de la grosseurs des graines dans le groupe des variétés tardives. Oléagineux, 22è année $\mathrm{n} 11$. Revue internationale des corps gras. Pp. 673676 .

Nisar Ahmed (1995)Heterosis, combining ability and inter relationships among yield and yield attributes in groundnut (ArachishypogaeaL.) M.Sc. (Ag.) Thesis, Andhra Pradesh Agricultural University, Hyderabad, India.

Rene Chaume R, Pernes J, Combes D, Rene J. 1973 Breeding of Panicum maximum. Adiopodoumé: ORSTOM: $11 \mathrm{p}$.

Sankara P., 1997. Evaluation des performances agronomique et de la résistance à la rouille (Puccinia arachidis Speg.) de génotypes d'arachide (Arachis hypogaea L.) pour la création d'un idéotype au Burkina Faso. Thèse de doctorat d'Etat- Université de Ouagadougou, 224 p. 03 BP 7021 Ouagadougou.
Simpson, C. E. 1991. Pathways for introgression of pest resistance into Arachis hypogaea L. Peanut Science 18:22-26.

Simpson, C. E., J. L. Starr, S. C. Nelson, K. E. Woodard And O. D.Smith., 1993. Registration of TXAG-6 and TXAG-7 peanut germplasm. Crop Science 33:1418.

Upadhyaya HD, Gopal K, Nadaf HL and Vigaya Kumar S. 1992 Combining ability studies for yield and its components in groundnut. Indian J. Gent. 52(1):1-6.

Varshney RK, Mohan SM, Gaur PM, Gangarao NV, Pandey MK, Bohra A, Sawargaonkar SL, Chitikineni A, Kimurto PK, Janila P, Saxena KB, Fikre A, Sharma M, Rathore A, Pratap A, Tripathi S, Datta S, Chaturvedi SK, Mallikarjuna N, Anuradha G, Babbar A, Choudhary AK, Mhase MB, Bharadwaj $\mathrm{CH}$, Mannur DM, Harer PN, Guo B,Guo B, Liang X, Nadarajan N, Gowda CL (2013). Achievements and prospects of genomics assisted breeding in three legume crops of the semi-arid tropics. BiotechnolAdv 31: 1120-1134

Zagre B., 2004 Hérédité de la précocité et de quelques caractères associés au rendement chez l'arachide (Arachis hypogaea L.). Thèse de docteur ingénieur. Université de Cocody, 110p. 